\title{
Analisis Perbandingan Nilai Akurasi Mekanisme Attention Bahdanau dan Luong pada Neural Machine Translation Bahasa Indonesia ke Bahasa Melayu Ketapang dengan Arsitektur Recurrent Neural Network
}

\author{
Wahyu Gunawan ${ }^{\# 1}$, Herry Sujaini ${ }^{\# 2}$, Tursina ${ }^{\# 3}$

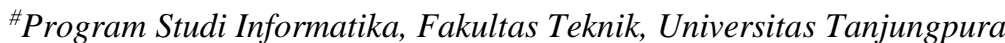 \\ Jl. Prof. Dr. H. Hadari Nawawi, Pontianak, 78124 \\ ${ }^{1}$ wahyugunawan11estudent. untan.ac.id \\ 2hseuntan.ac.id \\ 3tursinadinformatika.untan.ac.id
}

\begin{abstract}
Abstrak - Di Indonesia, penerapan mesin penerjemah masih banyak dilakukan dengan berbasis statistik khususnya dalam eksperimen penerjemahan bahasa daerah. Dalam beberapa tahun terakhir, mesin penerjemah jaringan saraf tiruan telah mencapai kesuksesan yang luar biasa dan menjadi metode pilihan baru dalam praktik mesin penerjemah. pada penelitian ini menggunakan mekanisme attention dari Bahdanau dan Luong dalam bahasa Indonesia ke bahasa Melayu Ketapang dengan data korpus paralel sejumlah 5000 baris kalimat. Hasil pengujian berdasarkan metode penambahan secara konsisten dengan jumlah epoch didapatkan nilai skor BLEU yaitu pada attention Bahdanau menghasilkan akurasi $35,96 \%$ tanpa out-of-vocabulary (OOV) dengan menggunakan jumlah epoch 40, sedangkan pada attention Luong menghasilkan akurasi 26,19\% tanpa OOV menggunakan jumlah 30 epoch. Hasil pengujian berdasarkan $\boldsymbol{k}$-fold cross validation didapatkan nilai rata-rata akurasi tertinggi sebesar $40,25 \%$ tanpa OOV untuk attention Bahdanau dan 30,38\% tanpa OOV untuk attention Luong, sedangkan pengujian manual oleh dua orang ahli bahasa memperoleh nilai akurasi sebesar $\mathbf{7 8 , 1 7 \%}$ dan $\mathbf{7 2 , 5 3 \%}$.
\end{abstract}

Kata kunci- Neural Machine Translation, Attention Mechanism, Deep Learning, Natural Language Processing, BLEU, K-Fold Cross Validation.

\section{PENDAhuluan}

Dalam beberapa tahun terakhir, mesin penerjemah masih banyak dilakukan dengan berbasis statistik (SMT) khususnya dalam eksperimen penerjemahan bahasa daerah di Indonesia.

Sampai saat ini kemunculan mesin penerjemah jaringan saraf tiruan (NMT) telah mencapai kesuksesan yang luar biasa dan menjadi metode pilihan baru dalam praktik mesin penerjemah. Mesin penerjemah jaringan saraf tiruan (NMT) telah mencapai pertunjukan mutakhir dalam menangani berbagai pasangan bahasa [1]. Penerapan NMT sudah banyak dilakukan pada beberapa pasangan bahasa resmi di Dunia, namun masih sedikit digunakan untuk eksperimen penerjemahan bahasa daerah, khususnya bahasa daerah di Indonesia.

Di Kalimantan Barat, bahasa Melayu Ketapang merupakan salah satu bahasa yang digunakan bagi masyarakat Kabupaten Ketapang. Bahasa Melayu Ketapang memiliki beberapa dialek dan pengelompokannya pun memiliki ciri-ciri yang berbeda, perbedaan meliputi sistem pengucapan, bentuk kata dan kosakata. Akan tetapi seiring bertambahnya waktu, penggunaan bahasa Melayu Ketapang semakin jarang digunakan dalam berkomunikasi oleh masyarakat. Akibat yang ditimbulkan banyak kata-kata dalam bahasa Melayu Ketapang yang mulai mengalami kepunahan [2]. Pemanfaatan mesin penerjemah dapat digunakan dalam upaya melestarikan bahasa daerah dengan cara digital.

Mesin penerjemah jaringan saraf tiruan (NMT) adalah pendekatan baru untuk teknologi mesin penerjemah yang menggabungkan encoder yaitu komponen jaringan saraf tiruan berulang (RNN) yang mengkodekan bahasa sumber dalam vektor panjang tetap, dan dekoder yaitu komponen jaringan saraf tiruan berulang (RNN) yang menghasilkan hasil terjemahan lengkap [3].

Dalam pengembangan mesin penerjemah jaringan saraf tiruan (NMT), beberapa peneliti dengan makalah sebelumnya yaitu arsitektur recurrent continuous translation models (RCTM) yang memadukan convolution neural network dan recurrent neural network [4], RNN encoder-decoder [5] dengan framework model yang biasa dikenal sequence to sequence [6], RNNsearch dengan 
mekanisme attention (alignment \& translate) [7], global dan local attention [8], ByteNet [9], convolution sequence to sequence (Conv Seq2Seq) [10] serta self-attention network (SAN) dengan arsitektur transformer [11].

Mesin penerjemah jaringan saraf tiruan (NMT) dibangun dari framework model sequence to sequence yang memiliki hal utama adalah dua jaringan saraf tiruan dengan arsitektur encoder dan decoder yang membaca kata sumber satu persatu untuk mendapatkan representasi vektor dari dimensi tetap (encoder), kemudian mengkondisikan input dan mengekstrak kata target satu per satu menggunakan RNN (decoder).

Masalah yang terdapat pada sequence to sequence adalah bahwa satu-satunya informasi yang diterima decoder dari encoder adalah encoder hidden state (representasi vektor yang seperti ringkasan numerik dari urutan input) yang mempunyai node panjang tetap dan tidak memungkinkan memiliki panjang yang sama seperti urutan input pada encoder. Jadi, untuk teks input yang panjang, mengharapkan decoder hanya menggunakan satu representasi vektor untuk meringkas urutan input sehingga bisa menghasilkan terjemahan. Kasus seperti ini apabila mengatasi teks input yang panjang atau banyak akan menyebabkan mesin penerjemah sulit mengingat urutan. Hal yang bisa mengatasi ini adalah kita perlu satu representasi vektor dari setiap langkah encoder pada setiap input perkata ini bisa disebut attention.

Untuk mengatasi masalah yang ada pada sequence to sequence adalah dengan menggunakan mekanisme attention. Attention adalah antarmuka antara encoder dan decoder yang menyediakan decoder dengan informasi dari setiap encoder hidden state. Dengan ini, model dapat secara selektif fokus pada bagian-bagian berguna dari urutan input dan mempelajari alignment atau penyelarasan di antara urutan input dan output. Mekanisme attention bisa membuat satu representasi vektor dari setiap langkah waktu encoder sehingga akan membantu model untuk mengatasi secara efektif pada kalimat input yang panjang dan membuat akurasi terjemahan menjadi lebih baik.

Beberapa penelitian terkait mekanisme attention pada mesin penerjemah jaringan saraf tiruan telah dilakukan. Penelitian yang dilakukan oleh Bahdanau dkk [7] membuat penerjemahan bahasa Inggris ke bahasa Prancis dengan 348 juta korpus pelatihan dengan menggunakan 2 metode pengujian berdasarkan panjang kata yaitu 30 kata dan 50 kata, yang masing-masing diuji dengan dan tanpa attention. Akurasi tertinggi yang dihasilkan sebesar 36,15 skor BLEU tanpa OOV pada model panjang 50 kata dengan attention. Kemudian, penelitian dari Luong dkk [8] melakukan eksperimen pada penerjemahan bahasa Inggris ke Bahasa Jerman dengan 4,5 juta korpus pelatihan dengan penambahan pendekatan lokal dan global attention. akurasi tertingginya adalah sebesar 25,9 skor BLEU. Selain itu, penelitian dari Abidin dkk [3] melakukan penerjemahan bahasa Lampung ke bahasa Indonesia dengan 3000 korpus pelatihan, pengujian berdasarkan kalimat tunggal dan majemuk dengan dan tanpa OOV. Akurasi tertinggi yang dihasilkan adalah sebesar 51,69\% skor BLEU.
Berdasarkan permasalahan yang telah diuraikan, maka dalam penelitian ini akan mengimplementasikan mesin penerjemah jaringan saraf tiruan (NMT) dengan arsitektur recurrent neural network (RNN) dan mekanisme attention Bahdanau dan Luong dari kedua mekanisme attention tersebut akan dilihat mana yang lebih akurat dan memiliki akurasi tertinggi dalam menerjemahkan dari bahasa Indonesia ke bahasa Melayu ketapang berdasarkan hasil pengujian otomatis oleh BLEU (Bilingual Evaluation Understudy) dan pengujian manual oleh ahli bahasa

\section{LANDASAN TEORI}

Model sequence to sequence merujuk pada makalah penelitian yang berjudul "Sequence to Sequence Learning with Neural Networks" [6] yang mengimplementasikan encoder-decoder model untuk neural machine translation (NMT). Selain itu juga ada versi modifikasi dari encoderdecoder yang digunakan untuk image captioning pada makalah penelitian yang berjudul "Deep Visual-Semantic Alignments for Generating Image Descriptions" [12].

Salah satu motivasi dibalik pendekatan yang diusulkan dari mekanisme attention adalah penggunaan context vector yang memiliki panjang tetap (fix-length) pada encoder-decoder dasar. Keterbatasan ini dapat membuat pendekatan encoder-decoder dasar berkinerja buruk pada kalimat yang panjang. Pendekatan yang diusulkan menyediakan cara intuitif untuk memeriksa alignment (soft-) antara kata dalam terjemahan yang dihasilkan dengan kata kalimat sumber[7]. Mekanisme attention yang diterapkan pada NMT sebagai berikut :

- Attention Bahdanau

- Attention Luong

\section{A. Attention Bahdanau}

Attention Bahdanau atau biasa yang dikenal dengan additive attention merupakan salah satu jenis mekanisme attention yang diperkenalkan lebih dulu pada mesin penerjemah jaringan saraf tiruan (NMT) pada makalah penelitian dengan judul "Neural Machine Translation by Jointly Learning to Align and Translate" [7].

Dalam attention Bahdanau, cara untuk menghitung skor alignment, yaitu dengan concat/additive [13]. Dapat dilihat seperti pada persamaan 1 .

$$
\operatorname{score}\left(\boldsymbol{h}_{t}, \overline{\boldsymbol{h}}_{s}\right)=\boldsymbol{v}_{a}^{\top} \tanh \left(\boldsymbol{W}_{1} \boldsymbol{h}_{t}+\boldsymbol{W}_{\mathbf{2}} \overline{\boldsymbol{h}}_{s}\right)
$$

Cara alignment score dihitung di attention Bahdanau, dimana decoder hidden state dan encoder hidden state dikalikan dengan bobot matrix terlebih dahulu untuk mendapatkan bobot matrix masing-masing kemudian dijumlahkan. fungsi aktivasi tanh akan dikalikan dengan bobot matrix untuk menghasilkan alignment score [14].

\section{B. Attention Luong}

Attention Luong atau biasa yang dikenal dengan Multiplicative attention merupakan salah satu jenis mekanisme attention yang dilakukan pada mesin penerjemah jaringan saraf tiruan (NMT) pada makalah 
penelitian dengan judul "Effective Approaches to Attention-Based Neural Machine Translation"[8] telah berhasil menyederhanakan dan menggeneralisasi arsitektur dari attention Bahdanau[7].

Dalam attention Luong, ada tiga cara berbeda untuk menghitung skor alignment, seperti dot, general, dan concat [8]. Dapat dilihat pada persamaan 2.

$\operatorname{score}\left(\boldsymbol{h}_{t}, \overline{\boldsymbol{h}}_{s}\right)= \begin{cases}\boldsymbol{h}_{t}^{\top} \overline{\boldsymbol{h}}_{s} & \text { dot } \\ \boldsymbol{h}_{t}^{\top} \boldsymbol{W}_{a} \bar{h}_{s} & \text { general } \\ \boldsymbol{v}_{a}^{\top} \tanh \left(\boldsymbol{W}_{a}\left[\boldsymbol{h}_{t} ; \overline{\boldsymbol{h}}_{s}\right]\right) & \text { concat }\end{cases}$

Keterangan skor alignment sebagai berikut :

- Dot adalah fungsi yang paling sederhana, untuk menghasilkan alignment score kita hanya perlu mengambil encoder hidden state dan mengalikannya dengan decoder hidden state [14].

- General mirip dengan fungsi dot product perbedaannya dengan menambah bobot matrix dalam persamaannya [14].

- Concat sedikit mirip dengan cara skor alignment score yang dihitung di attention Bahdanau, perbedaannya adalah decoder hidden state dan encoder hidden state tidak akan memiliki bobot matrix masing-masing, melainkan hanya memiliki bobot matrix bersama [14].

\section{METODE PENELITIAN}

Tahapan metode penelitian dapat diilustrasikan pada bagan alur seperti ditunjukkan pada Gambar 1 .
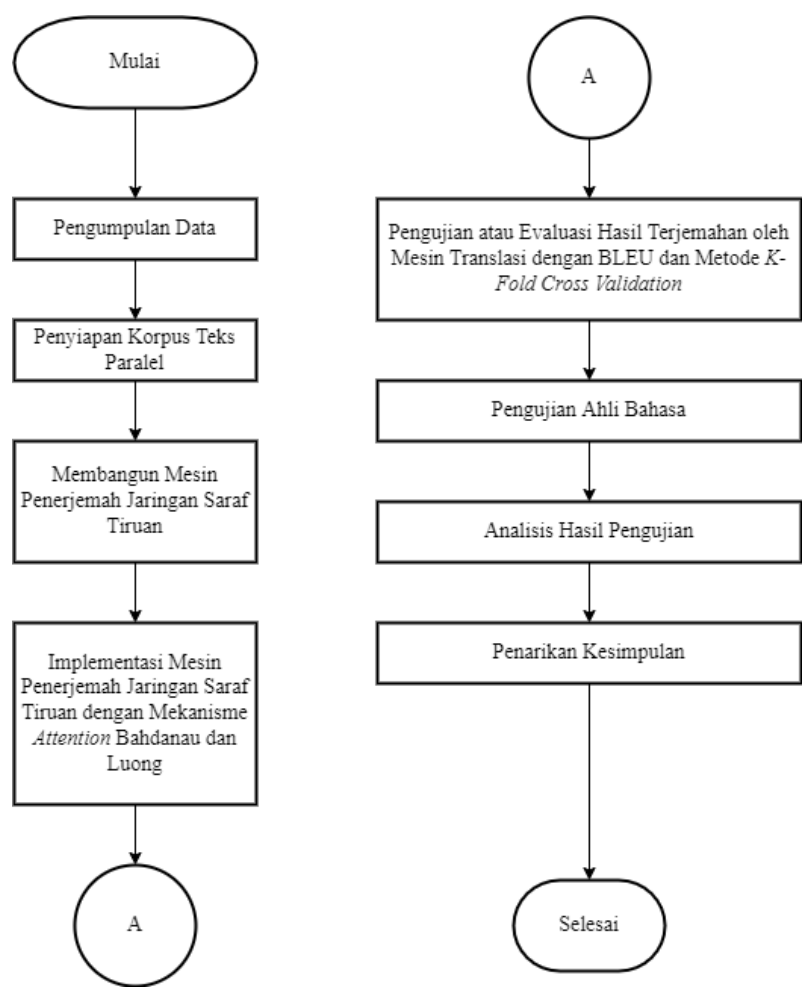

Gambar. 1 Metode penelitian

\section{A. Pengumpulan Data}

Pengumpulan data menggunakan metode observasi untuk memperoleh data yang diperlukan dalam penelitian. Adapun tahapan yang dilakukan adalah sebagai berikut.

1) Observasi : Dibutuhkan seorang ahli bahasa untuk mengkaji hasil terjemahan mesin dalam penelitian ini. Penulis melakukan observasi pada dua orang yang akan menjadi ahli bahasa dengan berdiskusi berdasarkan pengetahuan dan pemahaman mereka tentang bahasa Indonesia dan Melayu Ketapang dan persetujuan kesediaan untuk memeriksa hasil terjemahan mesin. Setelah mendapatkan data berupa orang yang menjadi narasumber, maka selanjutnya melakukan observasi dengan cara mencari korpus hasil penelitian dengan judul "Optimasi Korpus untuk Meningkatkan Nilai Akurasi Mesin Penerjemah Statistik (Studi Kasus Bahasa Indonesia ke Bahasa Melayu Ketapang)" [15] yang berasal dari buku novel Harry Potter and the Order of Phoenix, buku novel Laskar Pelangi. Kemudian hasil penelitian dengan judul "Perbandingan Metode Evaluasi Otomatis Terhadap Mesin Penerjemah Menggunakan Part of Speech" [16] yang berasal dari buku Chairul Tanjung Si Anak Singkong. Kemudian korpus yang dikumpulkan akan dijadikan bahan dalam melakukan penelitian.

\section{B. Penyiapan Korpus Paralel}

Korpus adalah kumpulan dari berbagai teks sebagai sumber penelitian linguistik dan sastra. Pada penelitian ini tersedia dua korpus paralel yang digunakan yaitu korpus bahasa Indonesia dan bahasa Melayu Ketapang. Adapun korpus paralel pada penelitian ini berupa bahasa Indonesia yang berasal dari penelitian Dinar [15] dan Rahayu [16]. Korpus paralel akan disimpan dengan nama file yang berbeda dan format file yang sama. Korpus tersebut digunakan dalam penelitian ini berjumlah 5000 baris kalimat.

Berikut contoh korpus paralel dalam bentuk file teks seperti pada Gambar 2.

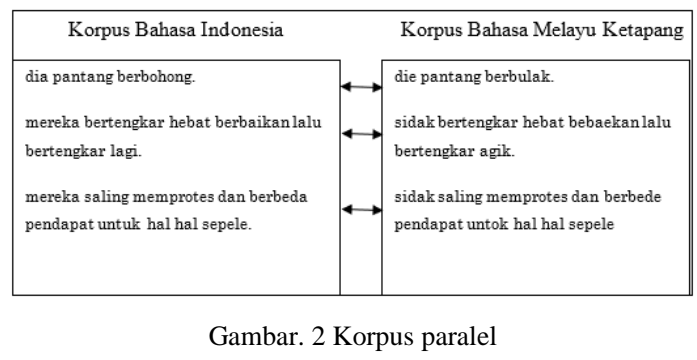

\section{Membangun Mesin Penerjemah Jaringan Saraf Tiruan}

Membangun mesin penerjemah jaringan saraf tiruan dilakukan dengan cara online atau daring dengan memanfaatkan layanan produk google, untuk instalasi perangkat lunak yang diperlukan adalah InterText untuk teks editor alignment kalimat korpus yang dipersiapkan untuk proses pelatihan nanti. Adapun produk google yang akan digunakan untuk membantu membangun mesin penerjemah jaringan saraf tiruan adalah sebagai berikut. 
- Browser Chrome untuk akses layanan produk Google.

- Google Drive untuk penyimpanan online data korpus dan model NMT.

- Google Colab untuk implementasi menjalankan program NMT.

- Framework Deeplearning TensorFlow untuk code program open-source NMT.

\section{Implementasi Mesin Penerjemah Jaringan Saraf} Tiruan dengan Mekanisme Attention

Arsitektur mesin penerjemah jaringan saraf tiruan bahasa Indonesia ke bahasa Melayu Ketapang terdiri dari beberapa tahapan, yaitu encoder, mekanisme attention, decoder, loss function, pelatihan model NMT dengan teknik teacher forcing berdasarkan jumlah epoch, prediksi model, dan menghitung akurasi terjemahan dengan skor BLEU. Arsitektur mesin penerjemah jaringan saraf tiruan seperti ditunjukkan pada Gambar 3.

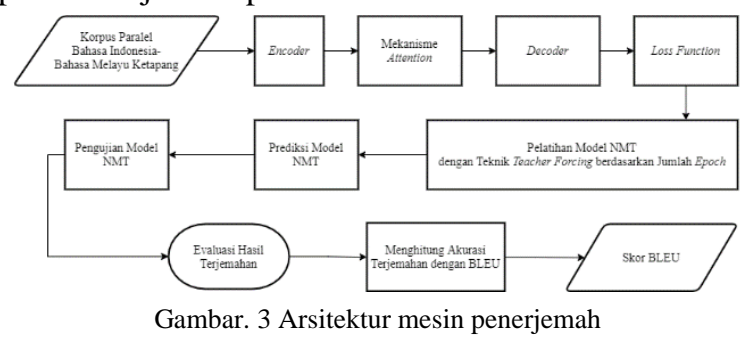

Tahapan yang dilewati sebagai berikut.

1) Encoder : tahapan yang diawali dengan memproses bahasa sumber dan menghasilkan pemetaan setiap kata dalam suatu bahasa ke bilangan bulat unik atau integer. Hal ini penting karena komputer hanya memahami angka, bukan string ataupun karakter. Dalam prosesnya akan menghasilkan struktur data kamus yaitu memetakan setiap kata ke bilangan bulat unik atau sebaliknya.

2) Mekanisme Attention : tahapan penghubung antara encoder dan decoder, yang memiliki peran dalam mempelajari dan menentukan nilai skor penyelarasan/alignment urutan input. hal yang mendasar pada mekanisme attention terdapat pada fungsi penghitungan skor. Ada banyak cara penghitungan skor yang diajukan oleh para peneliti sebelumnya, seperti Bahdanau dengan concat/additive sedangkan Luong dengan dot product, general, dan concat. pada penelitian ini menggunakan attention Bahdanau dengan concat/additive sedangkan attention Luong dengan dot product.

3) Decoder: tahapan untuk menghasilkan output berupa prediksi kata pada setiap time step berdasarkan proses yang telah dilewati sebelumnya. Sama halnya seperti encoder pada decoder kita sama-sama memiliki akses dua layer, akan tetapi disini memakai bantuan attention layer untuk menghasilkan output. Attention layer menyediakan informasi berupa attention vector yang menyimpan attention weight dari seluruh encoder hidden state, sehingga memberi tahu decoder apa yang harus difokuskan pada setiap time step. Output yang dihasilkan pada setiap time step decoder memiliki peran sebagai input pada context vector selanjutnya.

4) Loss Function : tahapan yang menggunakan teknik optimasi dalam proses pelatihan model, tujuannya untuk meminimalkan nilai loss function. Semakin rendah nilainya maka semakin baik modelnya. Model yang sempurna memiliki nilai loss function 0 . Selanjutnya model lengkap siap untuk dilatih, proses pelatihan ini dimulai dengan menentukan nilai loss function terlebih dahulu. Model melatih dataset yang memiliki representasi bilangan bulat unik atau integer kemudian dihimpun menjadi data tensor oleh karena itu perlu menggunakan modul sparse categorical cross entropy karena memiliki banyak kategori (jumlah kata sumber dan target). Kemudian dilanjutkan dengan proses pelatihan model NMT.

5) Pelatihan Model NMT : tahapan untuk melatih model dengan memanfaatkan data latih menggunakan teknik dan waktu tertentu sehingga model dapat digunakan untuk menghasilkan prediksi. Dalam langkah pelatihan tunggal, akan melewati input tensor yang mewakili kalimat input dari encoder. Hal ini mengembalikan encoder output yang berisi hidden state dari semua time step. kemudian memastikan hidden state terakhir dari encoder digunakan sebagai inisiasi untuk hidden state awal dari decoder. Pada pelatihan model ini membutuhkan teknik teacher forcing dan penentuan jumlah epoch. Teacher forcing adalah metode pelatihan yang penting dalam model deep learning di NLP. Hal ini merupakan cara untuk melatih model recurrent neural network dengan cepat dan efisien yang menggunakan output aktual dari time step sebelumnya sebagai input [17].

6) Prediksi Model NMT: Saat melatih model NMT dan menyelesaikan pelatihan. Selanjutnya memperoleh terjemahan yang diberikan dari kalimat sumber yang tidak dilihat sebelumnya pada pelatihan, proses ini disebut inference. Ada perbedaan jelas antara pelatihan dan inference. pada waktu inference yang dilakukan hanya memiliki akses ke kalimat sumber, yaitu encoder output shape. Ada cara untuk melakukan decoding, beberapa metode decoding termasuk greedy search dan beam search. Tetapi dalam penelitian ini menggunakan greedy search yang merujuk pada framework deep learning tensorflow [18]

7) Pengujian Model NMT : Pengujian model NMT diawali dengan pengujian input manual, pengujian data uji otomatis, dan mencetak hasil terjemahan model NMT. Pengujian input manual adalah pengujian dengan menginputkan kalimat secara manual pada program. Pengujian data uji otomatis adalah pengujian dengan menggunakan data kalimat uji yang terdiri dari beberapa baris kalimat uji dengan jumlah tertentu, sehingga dapat menerjemahkan berdasarkan baris di dalam kalimat tersebut atau menerjemahkan seluruh baris kalimat. Setelah melakukan proses penerjemahan data uji otomatis selanjutnya dapat melihat output yang dihasilkan berupa 
file .txt yang menyimpan data kalimat sumber/input, kalimat aktual/target sebenarnya, dan kalimat terjemahan

8) Evaluasi Hasil Terjemahan : Hasil terjemahan dievaluasi secara otomatis. pengujian otomatis dilakukan menggunakan metode penambahan jumlah epoch secara konsisten dan metode $k$-fold cross validation

9) Menghitung Akurasi Terjemahan dengan BLEU : Pengujian hasil terjemahan dilakukan dengan otomatis. Pengujian dilakukan untuk mendapatkan keakuratan mesin penerjemah berdasarkan nilai akurasi. Proses pengujian secara otomatis pada penelitian ini menggunakan skor BLEU. BLEU mengukur nilai modified $n$-gram precision score antara hasil terjemahan mesin dengan terjemahan referensi dan menggunakan konstanta yang disebut brevity penalty. Nilai BLEU adalah hasil dari perkalian antara ratarata geometri dari modified precision score dengan brevity penalty. [19].

\section{E. Pengujian atau Evaluasi oleh Mesin Penerjemah Jaringan Saraf Tiruan}

Mesin penerjemah jaringan saraf tiruan dievaluasi secara otomatis dan manual. pengujian otomatis dilakukan menggunakan metode penambahan jumlah epoch secara konsisten dan metode $k$-fold cross validation. Penggunaan metode $k$-fold cross validation bertujuan untuk mencari nilai yang lebih akurat dan rata-rata dari akurasi yang dihasilkan. Pengujian manual adalah salah satu metode pengujian yang paling akurat, tetapi memakan waktu karena ahli bahasa melakukannya secara manual.

Gambar 4 merupakan grafik hasil perbandingan pengujian oleh BLEU berdasarkan jumlah epoch, dengan 6 kali percobaan dengan penambahan epoch secara konsisten sebesar 10 epoch.

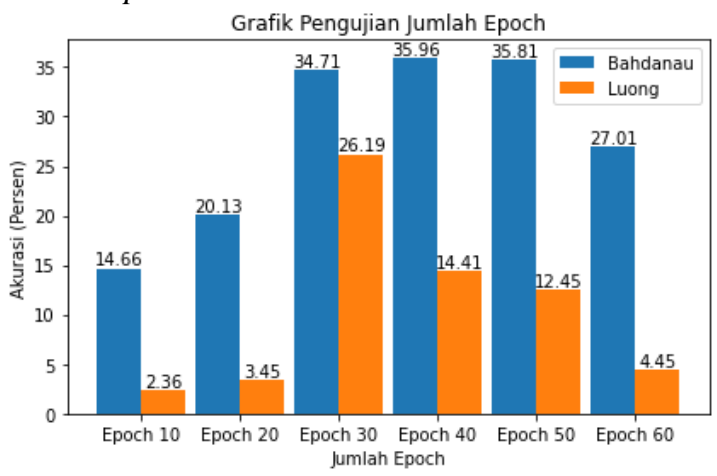

Gambar. 4 Grafik hasil pengujian oleh BLEU berdasarkan jumlah epoch

Berdasarkan hasil dari pengujian oleh BLEU, akan diambil epoch yang menunjukkan nilai akurasi tertinggi kedua mekanisme attention seperti terlihat pada Gambar 4 nilai skor BLEU yang tertinggi terdapat pada epoch 40 untuk attention Bahdanau dengan nilai 35,96\% dan epoch 30 untuk attention Luong dengan nilai 26,19\%, maka masing-masing attention berdasarkan epochnya inilah akan digunakan pada metode $k$-fold cross validation

Dalam penelitian ini digunakan 10 percobaan dengan total 5.000 kalimat korpus paralel dalam bahasa Indonesia dan Melayu Ketapang dengan format 500 kalimat uji dan 500 kalimat latih.

\begin{tabular}{|l|l|l|l|l|l|l|l|l|l|}
\hline 1 & 2 & 3 & 4 & 5 & 6 & 7 & 8 & 9 & 10 \\
\hline 1 & 2 & 3 & 4 & 5 & 6 & 7 & 8 & 9 & 10 \\
\hline 1 & 2 & 3 & 4 & 5 & 6 & 7 & 8 & 9 & 10 \\
\hline & & & & & & & & & \\
\hline 1 & 2 & 3 & 4 & 5 & 6 & 7 & 8 & 9 & 10 \\
\hline & & & & & & & & & \\
\hline 1 & 2 & 3 & 4 & 5 & 6 & 7 & 8 & 9 & 10 \\
\hline & & & & & & & & & \\
\hline 1 & 2 & 3 & 4 & 5 & 6 & 7 & 8 & 9 & 10 \\
\hline & & & & & & & & & \\
\hline 1 & 2 & 3 & 4 & 5 & 6 & 7 & 8 & 9 & 10 \\
\hline & & & & & & & & & \\
\hline 1 & 2 & 3 & 4 & 5 & 6 & 7 & 8 & 9 & 10 \\
\hline & & & & & & & & & \\
\hline 1 & 2 & 3 & 4 & 5 & 6 & 7 & 8 & 9 & 10 \\
\hline & & & & & & & & & \\
\hline 1 & 2 & 3 & 4 & 5 & 6 & 7 & 8 & 9 & 10 \\
\hline & & & & & & & & \\
\hline & & & Data Pengujian & & & & \\
\hline & & & Data Pelatihan & & & & \\
\hline
\end{tabular}

Gambar. 5 Pengujian dengan metode $k$-fold cross validation

Gambar 5 adalah pengujian menggunakan metode $k$-fold cross validation pada 5.000 baris kalimat, dengan 10 percobaan yang dilakukan dan setiap percobaan terdiri dari 500 kalimat sebagai korpus uji.

Keterangan

1. Data Uji $=$ Kalimat $1-500$

2. Data Uji $=$ Kalimat $501-1.000$

3. Data Uji $=$ Kalimat $1.001-1.500$

4. Data Uji $=$ Kalimat $1.501-2.000$

5. Data Uji $=$ Kalimat $2.001-2.500$

6. Data Uji $=$ Kalimat $2.501-3.000$

7. Data Uji $=$ Kalimat $3.001-3.500$

8. Data Uji $=$ Kalimat $3.501-4.000$

9. Data Uji $=$ Kalimat $4.001-4.500$

10. Data Uji $=$ Kalimat $4.501-5.000$

\section{F. Pengujian oleh Ahli Bahasa}

Pengujian oleh ahli bahasa dilakukan ketika hasil evaluasi mesin penerjemah jaringan saraf tiruan dengan BLEU telah dilakukan dengan menggunakan metode $k$-fold cross validation. pengujian oleh ahli bahasa digunakan untuk menentukan apakah hasil terjemahan dari mesin penerjemahan jaringan saraf tiruan mendekati atau bahkan cocok dengan terjemahan para ahli bahasa. Berikut proses evaluasi oleh ahli bahasa seperti terlihat pada Gambar 6.

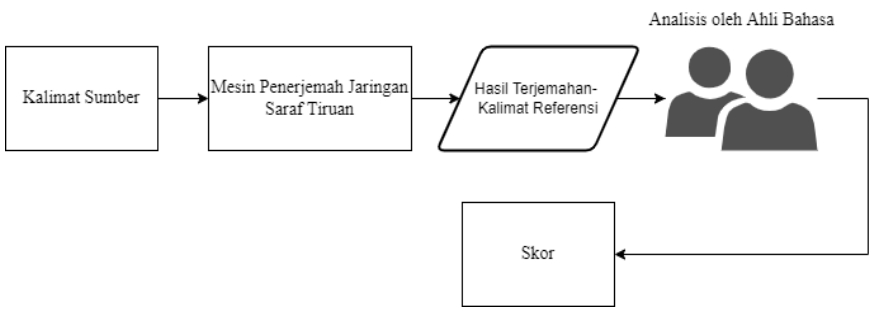

Gambar. 6 Proses evaluasi secara manual oleh ahli bahasa 


\section{G. Analisis Hasil Pengujian}

Analisis hasil pengujian dilakukan untuk menentukan mekanisme attention mana yang memiliki skor akurasi hasil terjemahan tertinggi dan faktor-faktor apa yang mempengaruhi mengapa akurasi mekanisme attention tersebut memiliki akurasi terbaik. beberapa percobaan dilakukan pada kedua mekanisme attention yang diawali dengan memakai metode penambahan jumlah epoch secara konsisten, lalu jumlah epoch ini diterapkan pada kedua mekanisme attention yang selanjutnya akan diterapkan metode $k$-fold cross validation untuk mendapatkan nilai rata-rata akurasi dari keseluruhan data korpus paralel pada mesin penerjemah jaringan saraf tiruan.

\section{H. Penarikan Kesimpulan}

Kesimpulan diambil dengan melihat hasil analisis yang dilakukan dengan membandingkan nilai akurasi mesin penerjemah jaringan saraf tiruan menggunakan dua mekanisme attention, kemudian melihat mekanisme attention mana yang memiliki nilai akurasi terbaik berdasarkan hasil pengujian otomatis oleh BLEU dan Ahli bahasa.

\section{HASIL DAN PEMBAHASAN}

Pengujian dilakukan dengan dua cara, pertama secara otomatis oleh BLEU dan kedua secara manual oleh ahli bahasa. Adapun Skenario pengujian penelitian ini seperti terlihat pada Tabel 1.

TABEL I

SKENARIO PENGUJIAN

\begin{tabular}{|c|c|c|}
\hline No & $\begin{array}{l}\text { Nama } \\
\text { Pengujian }\end{array}$ & Keterangan \\
\hline 1 & $\begin{array}{l}\text { Pengujian } \\
\text { dengan } \\
\text { jumlah epoch }\end{array}$ & $\begin{array}{l}\text { pengujian ini dilakukan dengan terus } \\
\text { menambahkan jumlah epoch secara } \\
\text { konsisten yaitu sebesar } 10 \text { epoch } \\
\text { sampai pada jumlah epoch yang hasil } \\
\text { akurasinya menurun yang dihitung } \\
\text { dengan skor BLEU, pada pengujian ini } \\
\text { menggunakan data uji } 1 \text { sebagai } \\
\text { sampel yaitu kalimat } 1 \text { sampai } 500 \\
\text { untuk korpus uji, sedangkan kalimat } \\
500-5000 \text { untuk korpus latih. Tujuan } \\
\text { pengujian ini adalah untuk mengetahui } \\
\text { mekanisme attention yang memiliki } \\
\text { nilai akurasi tertinggi berdasarkan } \\
\text { jumlah epoch, sehingga jumlah epoch } \\
\text { yang memberikan akurasi tertinggi } \\
\text { akan dipakai untuk pengujian } \\
\text { selanjutnya, serta menghitung jumlah } \\
\text { kalimat yang bisa diterjemahkan } \\
\text { berdasarkan jumlah epoch. }\end{array}$ \\
\hline 2 & $\begin{array}{l}\text { Pengujian } \\
\text { dengan } k \text {-fold } \\
\text { cross } \\
\text { validation }\end{array}$ & $\begin{array}{l}\text { Setelah dilakukan pengujian dengan } \\
\text { jumlah epoch, dapat dilihat masing- } \\
\text { masing mekanisme attention mana } \\
\text { yang nilai akurasinya paling tinggi, } \\
\text { selanjutnya diambil jumlah epoch } \\
\text { yang menghasilkan nilai akurasi } \\
\text { tertinggi, maka jumlah epoch } \\
\text { tersebutlah yang akan digunakan } \\
\text { dalam proses pelatihan. Data uji dibagi } \\
\text { menjadi } 10 \text { percobaan berdasarkan } \\
\text { jumlah korpus paralel yang digunakan } \\
\text { sebesar } 5000 \text { baris kalimat, sehingga }\end{array}$ \\
\hline
\end{tabular}

\begin{tabular}{|c|c|c|}
\hline No & $\begin{array}{l}\text { Nama } \\
\text { Pengujian }\end{array}$ & Keterangan \\
\hline & & $\begin{array}{l}\text { ditentukan korpus yang digunakan } \\
\text { untuk uji sebesar } 500 \text { baris kalimat. } \\
\text { Selanjutnya korpus uji yang } \\
\text { menunjukkan nilai akurasi tertinggi } \\
\text { digunakan sebagai korpus uji untuk } \\
\text { melakukan pengujian manual oleh ahli } \\
\text { bahasa.. }\end{array}$ \\
\hline 3 & $\begin{array}{l}\text { Pengujian } \\
\text { oleh ahli } \\
\text { bahasa }\end{array}$ & $\begin{array}{l}\text { Pada pengujian ini bertujuan untuk } \\
\text { mengkonfirmasi secara manual } \\
\text { kalimat kata demi kata dari korpus uji } \\
\text { yang diperoleh dari pengujian } \\
\text { sebelumnya sehingga persentase } \\
\text { pengujian manual ditemukan dari } \\
\text { jumlah kata yang benar menurut ahli } \\
\text { bahasa dibagi dengan jumlah kata } \\
\text { yang diterjemahkan oleh mesin } \\
\text { penerjemah jaringan saraf tiruan }\end{array}$ \\
\hline
\end{tabular}

Dalam pengujian otomatis oleh skor BLEU, tepatnya dengan metode penambahan jumlah epoch secara konsisten yaitu sebesar 10 epoch, dimulai dari epoch 10 sampai epoch 60, berhenti pada epoch 60 dikarenakan akurasi terjemahan pada epoch tersebut dinilai sudah menurun dari 2 langkah epoch sebelumnya, ini berlaku pada kedua model mekanisme attention. Pada pengujian ini memakai data Uji 1 sebagai sampel pengujian terdiri dari 500 korpus kalimat uji dan 4500 korpus kalimat latih. Data Uji 1 ini didapat pada pembagian data korpus berdasarkan $k$-fold cross validation dengan korpus kalimat ujinya diambil dari kalimat 1 sampai 500 sedangkan untuk korpus kalimat yang dilatih diambil dari kalimat 501 sampai 5000. Seperti pada Tabel 2 yang dimana nilai akurasi tertinggi pada mekanisme attention Bahdanau dengan menggunakan jumlah epoch 40 dan menghasilkan nilai skor BLEU 35,96\% tanpa out-of-vocabulary (OOV), diikuti nilai akurasi tertinggi pada mekanisme attention Luong dengan menerapkan jumlah epoch 30 dan menghasilkan nilai skor BLEU 26,19\% tanpa OOV.

TABEL II

GRAFIK HASIL PENGUJIAN OLEH BLEU BERDASARKAN JUMLAH EPOCH

\begin{tabular}{|c|c|c|c|}
\hline \multirow{2}{*}{ No } & \multirow{2}{*}{$\begin{array}{l}\text { Jumlah } \\
\text { Epoch }\end{array}$} & \multicolumn{2}{|c|}{ Mekanisme Attention } \\
\hline & & Bahdanau & Luong \\
\hline 1 & 10 & 14,66 & 2,36 \\
\hline 2 & 20 & 20,13 & 3,45 \\
\hline 3 & 30 & 34,71 & 26,19 \\
\hline 4 & 40 & 35,96 & 14,41 \\
\hline 5 & 50 & 35,81 & 12,45 \\
\hline 6 & 60 & 27,01 & 4,45 \\
\hline
\end{tabular}

Grafik hasil perbandingan waktu pelatihan pada Gambar 7 menunjukkan kedua mekanisme attention, bahwa semakin bertambahnya jumlah epoch maka semakin bertambah juga waktu pelatihan dalam membangun model NMT, dapat dilihat mekanisme attention Bahdanau memerlukan waktu pelatihan yang lebih tinggi atau memiliki kecepatan pelatihan yang lebih rendah dibandingkan attention Luong pada setiap pengujian dengan jumlah epoch. 


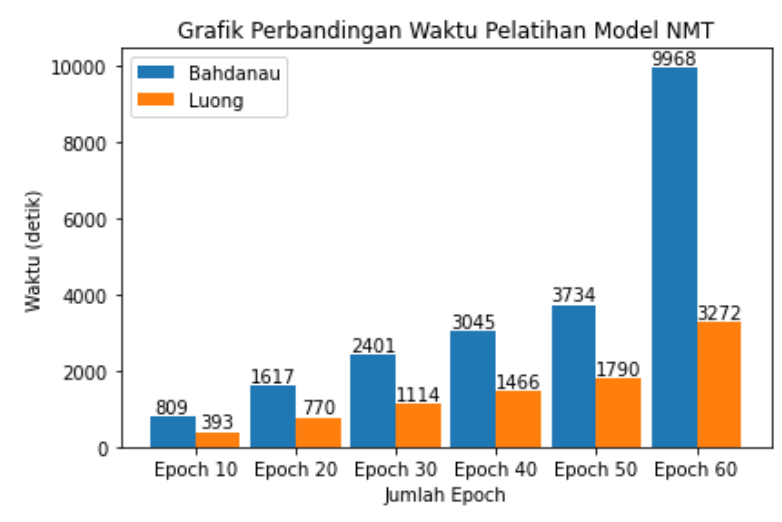

Gambar. 7 Grafik perbandingan waktu pelatihan model NMT

Dari pengujian yang telah dilakukan, jumlah epoch mempengaruhi nilai akurasi pada kedua mekanisme attention, tetapi disisi lain tidak mempengaruhi jumlah kalimat yang bisa diterjemahkan karena masalah utama di dalam model NMT ini adalah sulit menangani kalimat uji yang memiliki kata diluar kosakata data latih. Dari pengujian dengan menggunakan kalimat sebanyak 500 kalimat, yang bisa terjemahkan adalah 190 kalimat, sisa dari kalimat tersebut dilewatkan oleh model NMT karena tidak dapat menerjemahkan kalimat yang mengandung kata diluar kosakata data latih.

Setelah ditemukan jumlah epoch yang memberikan nilai akurasi tertinggi pada kedua mekanisme attention, selanjutnya menerapkan jumlah epoch tersebut pada kedua mekanisme attention. Metode pengujian yang dilakukan dengan menggunakan $k$-fold cross validation pada data $\mathrm{Uji}$ 2 sampai data Uji 10, untuk data Uji 1 sudah dilakukan dan nilainya sudah didapatkan sebagai sampel pengujian sebelumnya. Seperti hasil grafik pengujian pada Gambar 8. yang dimana nilai akurasi tertinggi pada mekanisme attention Bahdanau pada data Uji 10 dengan nilai skor BLUE $49,75 \%$, diikuti nilai akurasi tertinggi pada mekanisme attention Luong pada data Uji 7 dengan nilai skor BLEU 39,72\%.

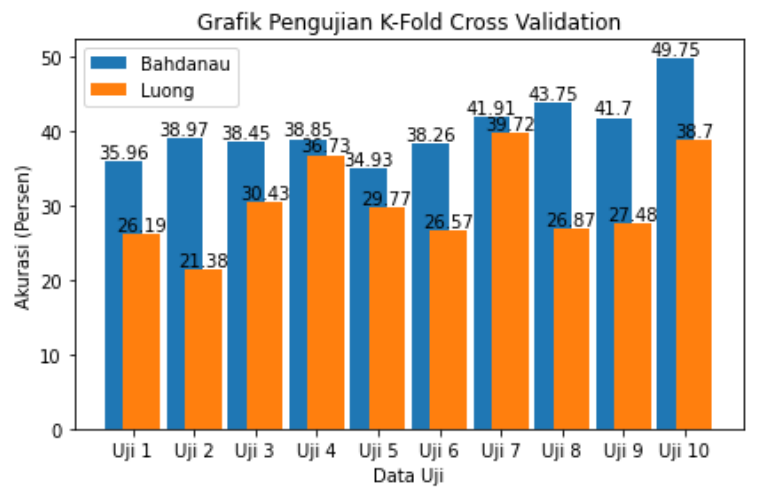

Gambar. 8 Grafik hasil pengujian oleh BLEU berdasarkan $k$-fold cross validation berdasarkan pembagian data uji

Tujuan penggunaan $k$-fold cross validation adalah untuk mengetahui nilai rata-rata dari kedua mekanisme attention. Adapun nilai rata-rata yang didapatkan pada pengujian menggunakan metode $k$-fold cross validation adalah $40,25 \%$ tanpa OOV untuk mekanisme attention Bahdanau dan 30,38\% tanpa OOV untuk mekanisme attention Luong serta jumlah kalimat paling banyak diterjemahkan oleh model NMT terdapat pada data Uji 3 sebanyak 196 kalimat sedangkan jumlah kalimat paling sedikit diterjemahkan terdapat pada data Uji 8 sebanyak 91 dengan nilai rata-rata kalimat yang dapat diterjemahkan oleh model NMT sebesar 163,6 kalimat seperti pada Tabel 3.

\section{TABEL III}

HASIL $K$-FOLD CROSS VALIDATION

\begin{tabular}{|l|l|l|l|l|}
\hline \multirow{2}{*}{ Uji } & \multirow{2}{*}{ Data Uji } & \multicolumn{2}{|c|}{ Mekanisme Attention } & \multirow{2}{*}{ Jumlah } \\
\cline { 3 - 4 } & & Bahdanau & Luong & \\
\hline 1 & $1-500$ & 35,96 & 26,19 & 190 \\
\hline 2 & $501-1000$ & 38,97 & 21,38 & 180 \\
\hline 3 & $1001-1500$ & 38,45 & 30,43 & $\mathbf{1 9 6}$ \\
\hline 4 & $1501-2000$ & 38,85 & 36,73 & 189 \\
\hline 5 & $2001-2500$ & 34,93 & 29,77 & 158 \\
\hline 6 & $2501-3000$ & 38,26 & 26,57 & 157 \\
\hline 7 & $3001-3500$ & 41,91 & $\mathbf{3 9 , 7 2}$ & 189 \\
\hline 8 & $3501-4000$ & 43,75 & 26,87 & $\mathbf{9 1}$ \\
\hline 9 & $4001-4500$ & 41,70 & 27,48 & 134 \\
\hline 10 & $4501-5000$ & $\mathbf{4 9 , 7 5}$ & 38,70 & $\mathbf{1 5 2}$ \\
\hline Total & 5000 & 402,53 & 303,84 & 1.636 \\
\hline $\begin{array}{l}\text { Rata- } \\
\text { rata }\end{array}$ & $\mathbf{5 0 0}$ & $\mathbf{4 0 , 2 5}$ & $\mathbf{3 0 , 3 8}$ & $\mathbf{1 6 3 , 6}$ \\
\hline
\end{tabular}

Pengujian manual oleh ahli bahasa Melayu Ketapang, pengujian manual dilakukan berdasarkan hasil pengujian otomatis menggunakan metode $k$-fold cross validation, dimana salah satu pengujian yang menunjukkan nilai akurasi tertinggi akan diambil untuk pengujian manual. Seperti pada Tabel 3 memperlihatkan 10 kali pengujian membuktikan seluruh hasil nilai akurasi yang diperoleh oleh attention Bahdanau lebih tinggi dibandingkan dengan attention Luong. Sehingga untuk melakukan pengujian manual oleh ahli bahasa akan menggunakan pengujian yang menunjukkan hasil akurasi dengan nilai tertinggi yang didapat pada mekanisme attention Bahdanau.

Adapun nilai tertinggi didapat pada mekanisme attention Bahdanau dilihat pada Tabel 3 menunjukkan data Uji 10 yang memiliki korpus kalimat uji 4501 sampai 5000 dan nilai akurasi sebesar $49,75 \%$ dengan jumlah kalimat terjemahan sebanyak 152 kalimat.

Setelah mendapatkan nilai tertinggi pada data uji, selanjutnya data uji dengan nilai tertinggi tersebut dilakukan pengujian kembali sebanyak 8 kali dengan metode $k$-fold cross validation menggunakan cara pembagian data uji seperti pada Tabel 4. Tujuan dari pengujian ini adalah untuk mengambil salah satu pengujian yang menunjukkan nilai akurasi tertinggi karena diketahui sebelumnya akurasi dari data Uji 10 memiliki nilai rata-rata akurasi sebesar $49,75 \%$, sehingga kemungkinan salah satu pengujian dari data Uji 10 akan menunjukkan akurasi tertinggi melebihi akurasi rata-rata. 
TABEL IV

HASIL K-FOLD CROSS VALIDATION DENGAN DATA UJI 10 SEBANYAK 152 KALIMAT

\begin{tabular}{|l|l|l|}
\hline Pengujian & \multicolumn{1}{|c|}{ Data Uji 10 } & $\begin{array}{l}\text { Jumlah } \\
\text { Kalimat }\end{array}$ \\
\hline 1 & $1-19$ & 49,49 \\
\hline 2 & $20-38$ & 44,87 \\
\hline 3 & $39-57$ & 48,83 \\
\hline 4 & $58-76$ & 41,67 \\
\hline 5 & $77-95$ & 50,09 \\
\hline 6 & $96-114$ & 54,29 \\
\hline 7 & $115-133$ & 53,48 \\
\hline 8 & $134-152$ & $\mathbf{5 6 , 0 6}$ \\
\hline
\end{tabular}

Setelah hasil semua pengujian diperoleh, pengujian dengan skor akurasi tertinggi terdapat pada pengujian ke 8 yang memiliki akurasi 56,06\% dengan jumlah kalimat yang diterjemahkan sejumlah 19 kalimat. Kemudian data dari pengujian ke 8 akan dijadikan sebagai data untuk pengujian manual oleh ahli bahasa, data ini selanjutnya akan dihitung persentase akurasi yang dihasilkan dalam pengujian manual dengan persamaan :

$$
\mathrm{P}=\frac{C}{R} x 100 \%
$$

$\mathrm{P}=$ Persentase akurasi

$\mathrm{C}=$ Jumlah kata yang diterjemahkan dengan tepat menurut penilaian

$\mathrm{R}=$ Jumlah kata hasil terjemahan

TABEL V

Hasil Nilai AKURAsi PENGUJian OLEH AHLI BAHASA

\begin{tabular}{|l|l|c|c|c|}
\hline No & $\begin{array}{c}\text { Nama Ahli Bahasa } \\
\text { Melayu Ketapang }\end{array}$ & $\mathbf{C}$ & $\mathbf{R}$ & $\mathbf{P}=\mathbf{C} / \mathbf{R} * \mathbf{1 0 0}$ \\
\hline 1 & Wijaya, S.Pd & 111 & 142 & $78,17 \%$ \\
\hline 2 & Hinsanol Laili, S.T & 103 & 142 & $72,53 \%$ \\
\hline
\end{tabular}

Hasil nilai akurasi pengujian ahli bahasa dapat dilihat pada Tabel 5 yang menunjukkan nilai akurasi dari 19 kalimat terjemahan oleh Wijaya, S.Pd. sebesar 78,17\%, sedangkan oleh Hinsanol Laili, S.T. sebesar 72,53\%.

\section{KESIMPULAN}

Dari hasil penelitian ini, dapat diambil kesimpulan bahwa berdasarkan pengujian dengan metode penambahan jumlah epoch secara konsisten sebesar 10 epoch, mekanisme attention terbaik yaitu attention Bahdanau menggunakan jumlah epoch 40 dengan memiliki nilai akurasi sebesar $35,95 \%$ tanpa out-of-vocabulary (OOV) dan attention Luong menggunakan jumlah epoch 30 dengan memiliki nilai akurasi 26,19\% tanpa OOV. Sehingga didapatkan attention Bahdanau memiliki nilai akurasi tertinggi mengungguli attention Luong dengan selisih nilai akurasi sebesar 9,77\%. Kemudian berdasarkan pengujian $k$-fold cross validation menunjukkan attention Bahdanau memiliki nilai akurasi diatas attention Luong pada seluruh data uji dengan memiliki nilai rata-rata akurasi sebesar 40,25\% tanpa OOV sedangkan 30,38\% tanpa OOV pada attention Luong. Terdapat selisih nilai akurasi sebesar $9,87 \%$, sehingga membuat attention Bahdanau dapat dikatakan lebih baik dibandingkan attention Luong. Selanjutnya penilaian hasil pengujian oleh ahli bahasa yang berbanding lurus dengan hasil terbaik dari pengujian menggunakan metode $k$-fold cross validation secara otomatis oleh skor BLEU pada pengujian kedelapan yang menghasilkan nilai akurasi sebesar 56,06\% dan hasil pengujian manual oleh Wijaya, S.Pd sebesar 78,17\% serta Hinsanol Laili, S.T sebesar 72,53\%. Berdasarkan hal tersebut, menunjukkan bahwa kualitas dari terjemahan manual sama baiknya dengan terjemahan mesin.

\section{REFERENSI}

[1] M. Junczys-Dowmunt, T. Dwojak, and H. Hoang, "Is Neural Machine Translation Ready for Deployment? A Case Study on 30 Translation Directions," 2016, [Online]. Available: http://arxiv.org/abs/1610.01108.

[2] A. Sulissusiawan, Struktur Bahasa Melayu Dialek Ketapang Pusat Pembinaan Dan Pengembangan N Nasional, 1998.

[3] Z. Abidin, A. Sucipto, and A. Budiman, "Penerjemahan Kalimat Bahasa Lampung-Indonesia Dengan Pendekatan Neural Machine Translation Berbasis Attention Translation of Sentence Lampung-Indonesian Languages With Neural Machine Translation Attention Based," J. Kelitbangan, vol. 06, no. 02, pp. 191-206, 2018.

[4] N. Kalchbrenner and P. Blunsom, "Recurrent continuous translation models," EMNLP 2013 - 2013 Conf. Empir. Methods Nat. Lang. Process. Proc. Conf., no. October, pp. 1700-1709, 2013.

$\mathrm{K}$. Cho et al., "Learning phrase representations using RNN encoder-decoder for statistical machine translation," EMNLP 2014 - 2014 Conf. Empir. Methods Nat. Lang. Process. Proc. Conf., pp. 1724-1734, 2014, doi: 10.3115/v1/d14-1179.

[6] I. Sutskever, O. Vinyals, and Q. V. Le, "Sequence to sequence learning with neural networks," Adv. Neural Inf. Process. Syst., vol. 4, no. January, pp. 3104-3112, 2014.

[7] D. Bahdanau, K. H. Cho, and Y. Bengio, "Neural machine translation by jointly learning to align and translate," $3 \mathrm{rd}$ Int. Conf. Learn. Represent. ICLR 2015 - Conf. Track Proc., pp. 1$15,2015$.

M.-T. Luong, H. Pham, and C. D. Manning, "Effective Approaches to Attention-based Neural Machine Translation," arXiv, 2015, [Online]. Available: https://re-work.co/blog/deeplearning-ilya-sutskever-google-openai.

[9] N. Kalchbrenner, L. Espeholt, K. Simonyan, A. van den Oord, A. Graves, and K. Kavukcuoglu, "Neural Machine Translation in Linear Time," 2016, [Online]. Available: http://arxiv.org/abs/1610.10099.

[10] J. Gehring, M. Auli, D. Grangier, D. Yarats, and Y. N. Dauphin, "Facebook使用 CNN 替代 RNN Convolutional Sequence to Sequence Learning," 2017, [Online]. Available: http://arxiv.org/abs/1705.03122.

[11] A. Vaswani et al., "Attention is all you need," Adv. Neural Inf. Process. Syst., vol. 2017-Decem, no. Nips, pp. 5999-6009, 2017.

[12] A. Karpathy and L. Fei-Fei, "Deep Visual-Semantic Alignments for Generating Image Descriptions," IEEE Trans. Pattern Anal. Mach. Intell., vol. 39, no. 4, pp. 664-676, 2017, doi: 10.1109/TPAMI.2016.2598339.

[13] Y. Marathe, "Neural Machine Translation using Bahdanau Attention Mechanism," medium.com, 2020. https://medium.com/analytics-vidhya/neural-machinetranslation-using-bahdanau-attention-mechanismd496c9be30c3 (accessed Jan. 20, 2021).

[14] G. Loye, "Attention Mechanism," blog.floydhub.com, 2019. https://blog.floydhub.com/attention-mechanism/ (accessed Jan. 20, 2021).

[15] S. T. Dinar, H. Sujaini, and N. Safriadi, "Optimasi Korpus untuk 
Meningkatkan Nilai Akurasi Mesin Penerjemah Statistik ( Studi Kasus Bahasa Indonesia ke Bahasa Melayu Ketapang ) Corpus Optimizing To Increase Value Of The Accuracy For Statistical Machine Translation ( Study Case Indonesia Language," 2020, doi: 10.26418 justin.v.

[16] D. T. Rahayu, H. Sujaini, and A. B. P. Negara, "Perbandingan Metode Evaluasi Otomatis Terhadap Mesin Penerjemah Statistik Menggunakan Part of Speech,”pp. 1-8, 2018.

[17] J. Brownlee, "What is Teacher Forcing for Recurrent Neural Networks?," machinelearningmastery.com, 2021. https://machinelearningmastery.com/teacher-forcing-forrecurrent-neural-networks/ (accessed Jan. 20, 2021).

[18] M.-T. Luong, "Neural Machine Translation," Stanford University, 2016.

[19] M. S. Islam and B. S. Purkayastha, "English to Bodo PhraseBased Statistical Machine Translation," in Advanced Computing and Communication Technologies, Springer, 2018, pp. 207-217. 